\title{
DETECTION OF INTER TURN FAULT IN TRANSFORMER WINDINGS BY PARAMETERS OF THEIR TRANSITION PROCESSES
}

\author{
R.G. Mustafin \\ Kazan State Power Engineering University, Kazan, Russia \\ ramil.mustafin@gmail.com
}

\begin{abstract}
The proposed method of detection the inter turn fault of transformer windings relates to the area of defectoscopy and allows detecting inter turn faults in a wide range of damaged (closed) turns. Power and instrument transformers with iron-core are widely used in power networks. As the insulation ages or is damaged, the wires between various transformer sections short circuits occur, which inevitably leads to a complete damage of the transformer. Shortcircuited part of the transformer forms an additional winding, the outputs of which are shortcircuited. The transition process of current increasing when DC voltage is connected to the transformer outputs occurs in diverse ways in undamaged (cut-off) winding section and in the damaged (short-circuited) section. The current growth rate in the undamaged section of the winding is determined by high magnetization inductance. The inductance of the short-circuited part of the winding is much less, so, the current growth rate in the short-circuited part is significantly greater than the current growth rate in the undamaged part of the winding. The article presents observations from computer models and real measurements of the substation auxiliary power transformer, which show the possibility of determining the presence of a turn fault in regards to the transition process parameters, the rate of current increase and decay in the transformer winding. The device aimed to find the inter turn faults in the transformer windings, working according to the proposed method will be quite simple and have a high sensitivity.
\end{abstract}

Keywords: transformer, ferromagnetic core, inter turn fault, transition process.

For citation: Mustafin RG. Detection of inter turn fault in transformer windings by parameters of their transition processes. Power engineering: research, equipment, technology. 2019; 21(3):1423. (In Russ). doi:10.30724/1998-9903-2019-21-3-14-23.

\section{ОБНАРУЖЕНИЯ ВИТКОВЫХ ЗАМЫКАНИЙ ОБМОТОК ТРАНСФОРМАТОРОВ ПО ПАРАМЕТРАМ ПЕРЕХОДНОГО ПРОЦЕССА}

\section{Р.Г. Мустафин}

\section{Казанский государственный энергетический университет, г. Казань, Россия ramil.mustafin@gmail.com}

\begin{abstract}
Резюме: Предлагаемая методика обнаружения витковых замыканий обмоток трансформаторов относится к области дефектоскопии и позволяет обнаруживать витковые замыкания в обмотках трансформатора в широком диапазоне поврежденных (замкнутых) витков. Силовые и измерительные трансформаторы с железным сердечником широко применяются в электроэнергетических сетях. При старении изоляции, при повреждении изолящии, в трансформаторах возникают замыкания между
\end{abstract}


витками из разных частей обмотки, что неизбежно приводит к полному повреждению трансформатора. Короткозамкнутая часть обмотки трансформатора образует дополнительную обмотку, выводы которой замкнуты накоротко. Переходный процесс роста тока при подключении постоянного напряжения к выводам трансформатора поразному происходит в неповрежденной (разомкнутой) части обмотки, и в поврежденной (короткозамкнутой) части. Скорость роста тока в неповрежденной части обмотки определяется большой величиной индуктивности намагничения. Индуктивность короткозамкнутой части обмотки значительно меньше, соответственно скорость роста тока в короткозамкнутой части существенно больше скорости роста тока в неповрежденной части обмотки. В статье приводятся наблюдения в компьютерной модели и в реальных измерениях на трансформаторе собственных нужд подстанции возможность определения наличия витковых замыканий по параметрам переходного процесса, по скорости нарастания и спада тока в обмотке трансформатора. Прибор, предназначенный для поиска витковых замыканий в обмотках трансформатора, работаюший по предлагаемой методике будет достаточно простым и иметь высокую чувствительность.

Ключевые слова: трансформатор, ферромагнитный сердечник, витковые замыкания, переходный прочесс.

\section{Introduction}

One of the most frequently-occurring transformer defects is the inter turn fault, when some of the transformer winding turns is short-circuited [1]. Usually, the presence of inter turn faults is detected from the parameters of the transformer normal operation at industrial frequency of $50 \mathrm{~Hz}$ [2-6]. Increasing the frequency range during measurements of transformer parameters can increase the sensitivity of detection methods of inter turn faults $[7,8]$.

In case of inter turn faults, two parts of a winding are formed: the undamaged part ( $\mathrm{A}$ in Fig. 1), which plays the role of the primary transformer winding, and short-circuited one (B in Fig. 1), which works as a secondary transformer winding.

To analyze the operation of the transformer winding with an inter turn fault, consider the Tshaped model [9] (Fig. 1), where the active resistance of the A turns is Ra; scattering inductance of the A turns is $L a$; active resistance of B turns is $R b$; scattering inductance of the B turns is $L b$; inductance of saturation is $L$ ' $O$ (which is less than the initial inductance $L o$ due to short-circuiting of $\mathrm{B}$ turns); $\mathrm{E}$ is the EMF connected to the winding. (All values are given for side A).

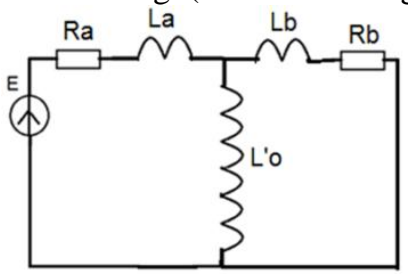

Fig. 1. T-shaped model of winding with inter turn fault (B turns)

Note that the scattering inductances of turns $L a$ and $L b$ are significantly less than the saturation inductance of $L^{\prime} o$, so the time constant $T a b$ (of the $R a-L a-L b-R b$ circuit), equal to, $T_{a b}=\left(L_{a}+L_{b}\right) /\left(R_{a}+R_{b}\right)$, is significantly less than the time constant $T^{\prime} o$ (of the $R a-L a-L$ 'o chain), which is equal to. $T_{o}^{\prime}=\left(L_{a}+L_{o}^{\prime}\right) / R_{a}$. Thus, the time constant $T a b$ of the winding with inter turn fault is significantly less than the time constant of the saturation circui $T^{\prime} o$ : $T_{a b} \ll T_{o}^{\prime}$ This difference governs the principle of detection the inter turn faults of transformer windings: the 
time constant is measured in wide range, and the presence of transients with a small transition time clearly indicates the winding short circuits in the transformer winding.

\section{Materials and methods}

To illustrate the operating principle of method for detection the inter turn fault of transformed windings, the Matlab/Simulink software was used to build the model (Figure 2).

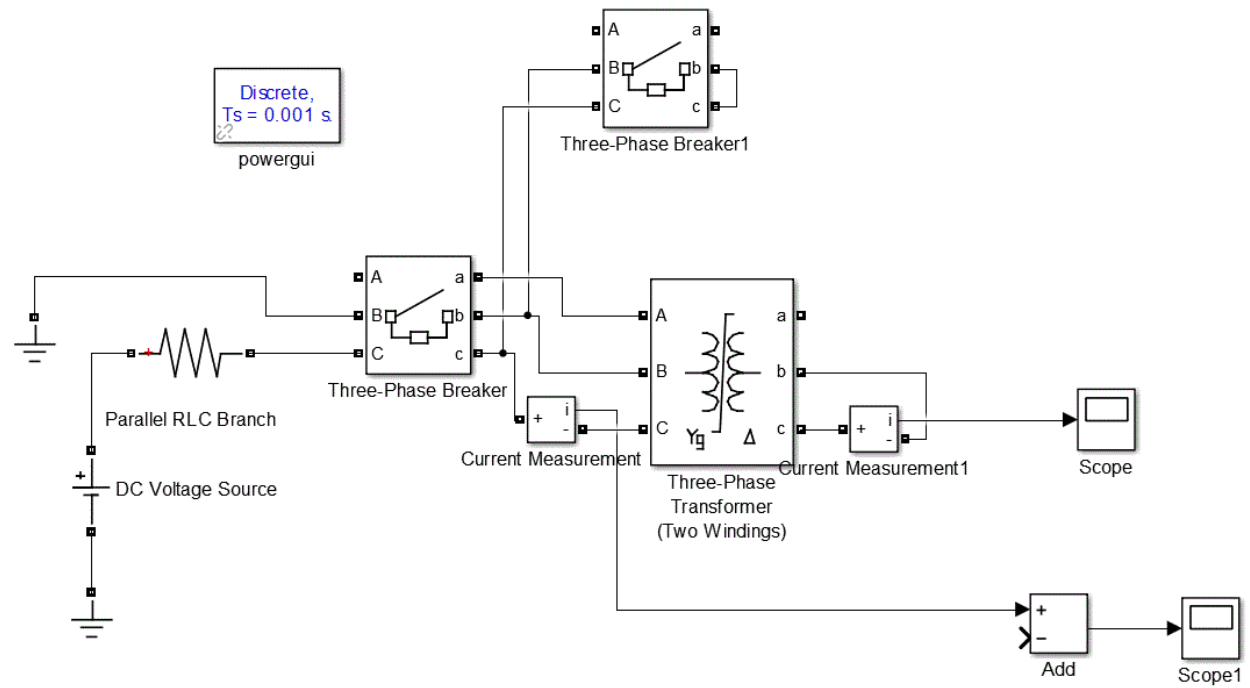

Fig. 2. The model of a transformer with a inter turn short-circuit, which is presented in the form of a short-circuited secondary transformer winding

Fig 3 presents the parameters of the three-phase transformer model.

A short-term DC voltage of $100 \mathrm{~V}$ (from DC Voltage Source in Fig. 2), is supplied to the primary winding of transformer (Three-Phase Transformer) through the current limiting resistance (Parallel RLC Branch) of $60 \mathrm{Ohms}$ active resistance. Three-phase breaker (Three-Phase Breaker) connects DC voltage to the primary winding of the transformer (to the $\mathrm{BC}$ winding) in 0.02 seconds after the model start-up. The second three-phase switch (Three-Phase Breakerl) closes the primary winding of the transformer (BC winding) in 0.5 seconds after the model start-up. Thus, magnetization of the transformer core occurs in the range of $0.02-0.5$ seconds (current increase in the primary winding), after 0.5 seconds, the demagnetization of the transformer core occurs (current drop in the primary winding). 


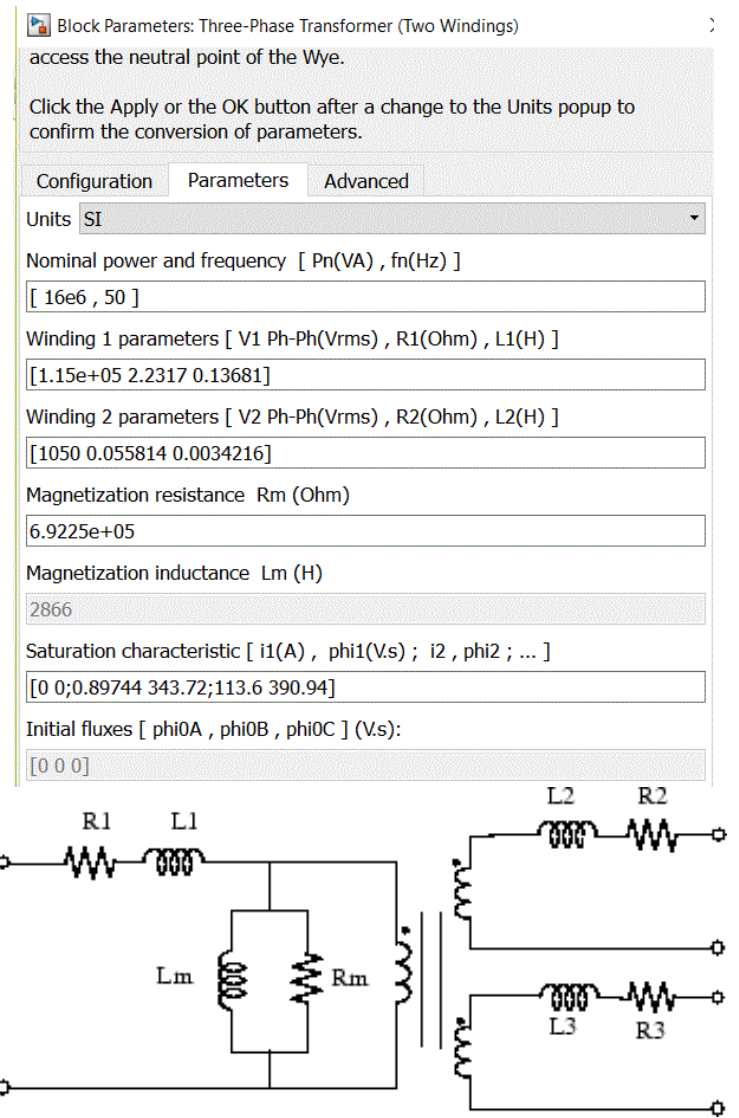

Fig. 3. Characteristics of transformer used in the model

In the absence of inter turn short circuits (secondary turns of the transformer $b c$ are not closed), the transformer magnetization inductance is high (Magnetization Inductance Lm $(H)$ in Fig. 3), consequently, the rate of magnetization current change is small (Fig. 4).

When a turn short circuit occurs (transformer secondary turns $b c$ are closed), the model has two magnetization inductances: the primary circuit BC and the short circuit of $b c$ turns. Moreover, the number of turns in the primary winding is much larger than the number of turns in the turn faults (as it can be seen in Fig. 3, from Winding 1 parameters V1 and Winding 2 parameters V2). Therefore, the magnetization inductance of the primary BC circuit is much greater than the magnetization inductance of the inter turn short circuit $b c$. This is reflected in the rate of increase and decrease of the magnetization current (Fig. 5): first (up to a time of the order of $0.1 \mathrm{~s}$ ), a rapid increase in current occurs in the inter turn short circuit bc. 


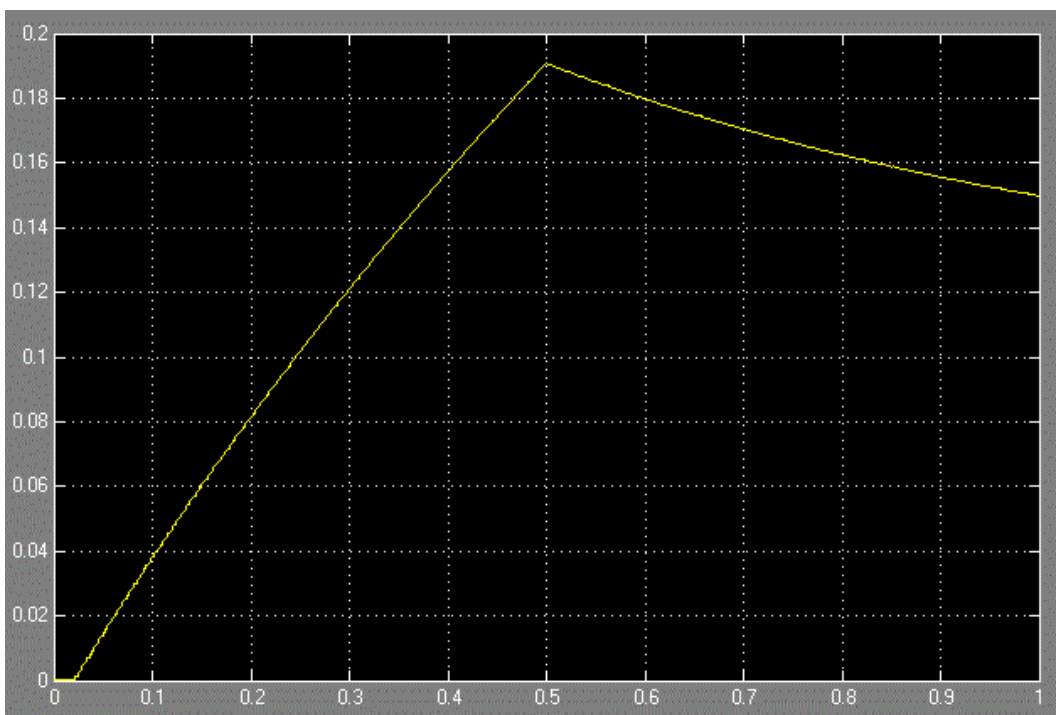

Fig. 4. Current in the primary winding $\mathrm{BC}$ in the absence of inter turn short circuits. Horizontal axis is time, s; vertical axis is current, A

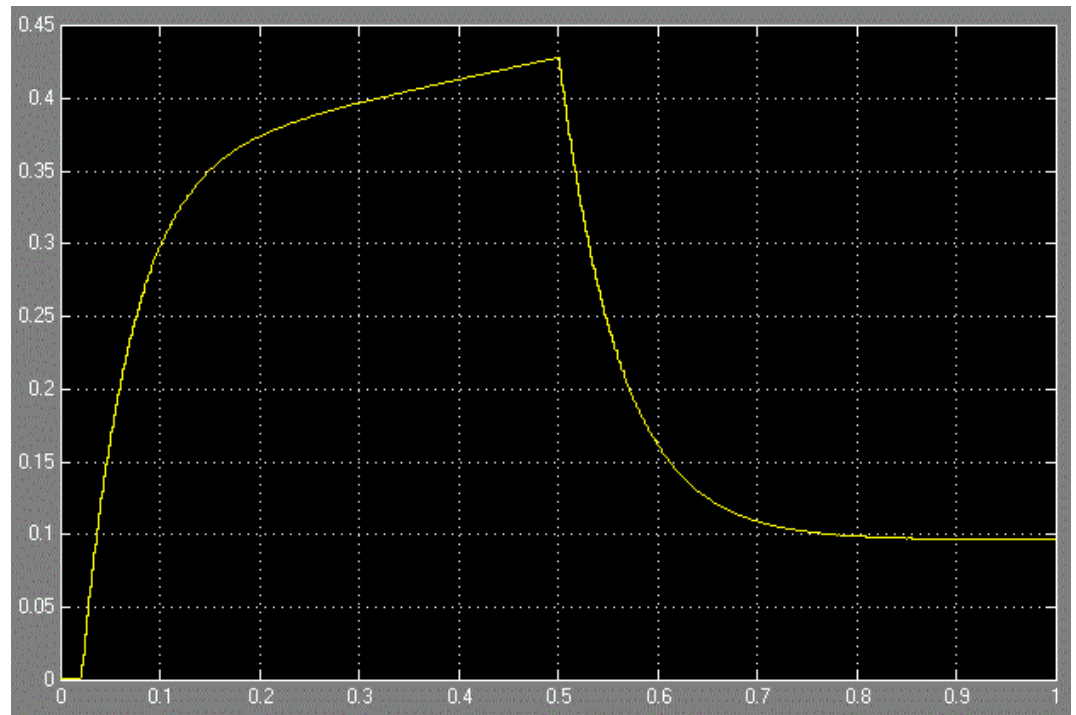

Fig. 5. Current in the primary winding BC in the presence of inter turn short circuits (the secondary transformer turns $b c$ are closed). Horizontal axis is time, s; vertical axis is current, A

After current saturation in inter turn short circuit (as shown in Fig. 6), only the slow growth of the magnetization current component in the primary winding $\mathrm{BC}$ remains (at times from about 0.2 to $0.5 \mathrm{~s}$ ). After the primary winding $\mathrm{BC}$ closes, a similar process occurs: a rapid decrease in the inter turn short circuit current (Fig. 6) (approximately in the range from 0.5 to $0.7 \mathrm{~s}$ ), then a slow decrease in the current in the primary BC circuit (see Fig. 5). 


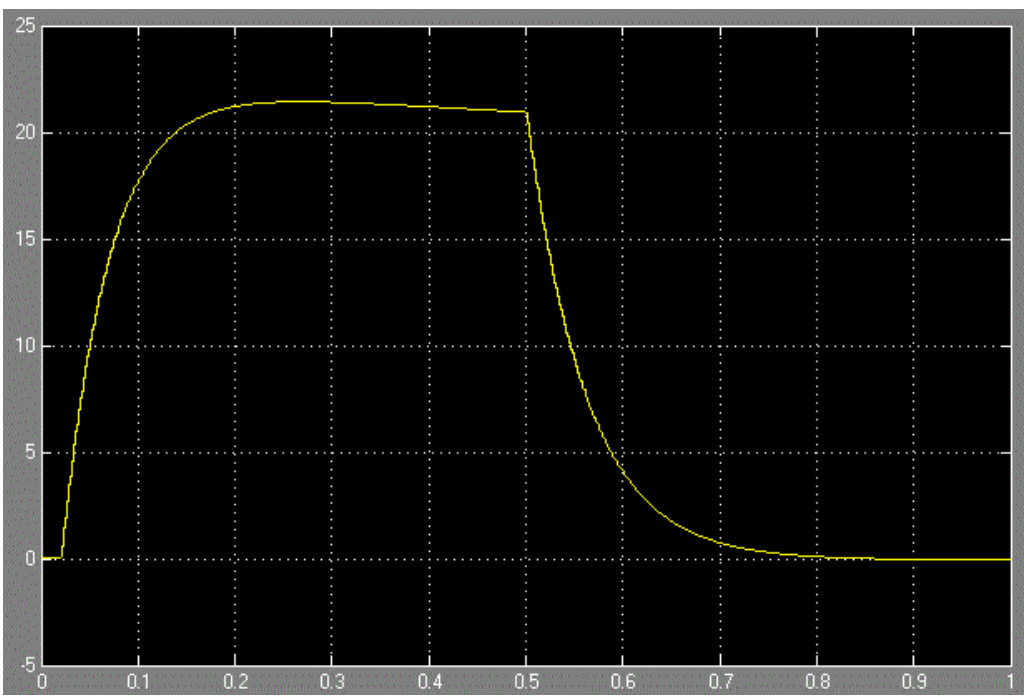

Fig. 6. Current in inter turn short circuits bc. Horizontal axis is time, s; vertical axis is current, A

\section{Results}

From the presented model of inter turn failures in transformers (Figs. 2 - 6), it can be seen that, based on the large difference in the rates of current change in the primary winding $\mathrm{BC}$ and in the inter turn short circuit $b c$, it becomes possible to create a device for detecting coil faults in transformer windings [10], using which the search for coil damage is significantly facilitated.

To verify and test the proposed methodology, transients were measured using an auxiliary transformer TSKS-40/145/10-UZ of Askold Electrotechnical Plant LLC (TU 3411-002-656534922010 , the transformer idle run current is not more than $12 \%$, power is $38 \mathrm{kVA}$, number of phases is 3 , frequency is $50 \mathrm{~Hz}$, degree of protection is IP 00 , rated voltage of $\mathrm{HV}$ winding is $10 \mathrm{kV}$, rated voltage of $\mathrm{HV}$ winding is $0.4 \mathrm{kV}$, rated current of $\mathrm{HV}$ winding is $2.19 \mathrm{~A}$, rated current of $\mathrm{LV}$ winding is $54.9 \mathrm{~A}$, short circuit voltage is $1.48 \%$, insulation class $\mathrm{F}$, circuit and group connection is $Y / Y n-O)$.

To record transients, the digital oscilloscope 6501 was used; the current in the transformer windings was measured by recording the voltage drop across the active resistance, connected in series with the measured transformer winding. Initially, a constant voltage of $8 \mathrm{~V}$ (through an active resistance of $47 \mathrm{Ohms}$ ) was applied to the primary $\mathrm{HV}$ winding of the transformer (BC pins). The current through the winding was measured by the voltage drop at a resistance of 10 Ohms, while the behavior of the transient process (with open - Fig. 7 and with closed - Fig. 8 turns of the secondary LV transformer windings) was similar to the picture observed in the Matlab/Simulink program (see Figs. 4, 5).

There are several ways for increasing the sensitivity of the proposed method:

1. By increasing DC voltage supplied to the transformer windings, while reducing the measurement time interval (to maintain the same current in the transformer winding).

2. By applying a constant voltage (measuring transient) in the windings of the lower voltage (LV).

3. By obtaining the reference measurements of the transient process in all windings of the undamaged (without winding short circuits) transformer. Further, during periodic measurements, the current transient measurements in the transformer windings should be compared with the saved reference measurements. 


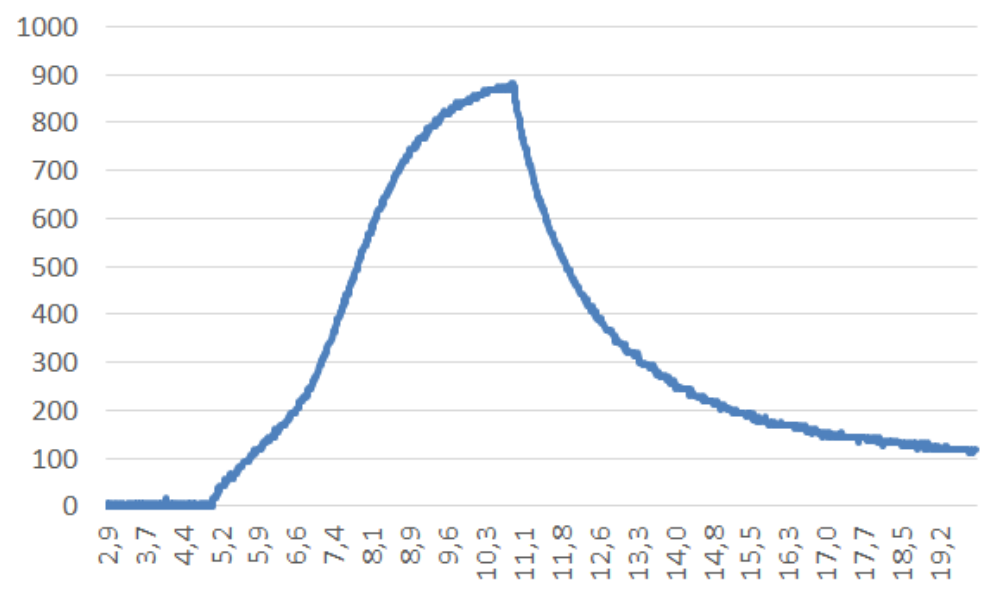

Fig. 7. The transient process in the primary HV winding (BC pins). At specific time (5 s) DC voltage of $8 \mathrm{~V}$ was connected to the $\mathrm{HV}$; at time of $11 \mathrm{~s} \mathrm{HV}$ winding was closed.

The $\mathrm{X}$ axis is time, $\mathrm{s}$; the $\mathrm{Y}$ axis is voltage amplitude, $\mathrm{mV}$, at a resistance of $10 \mathrm{Ohms}$ (current measurement in the HV primary winding)

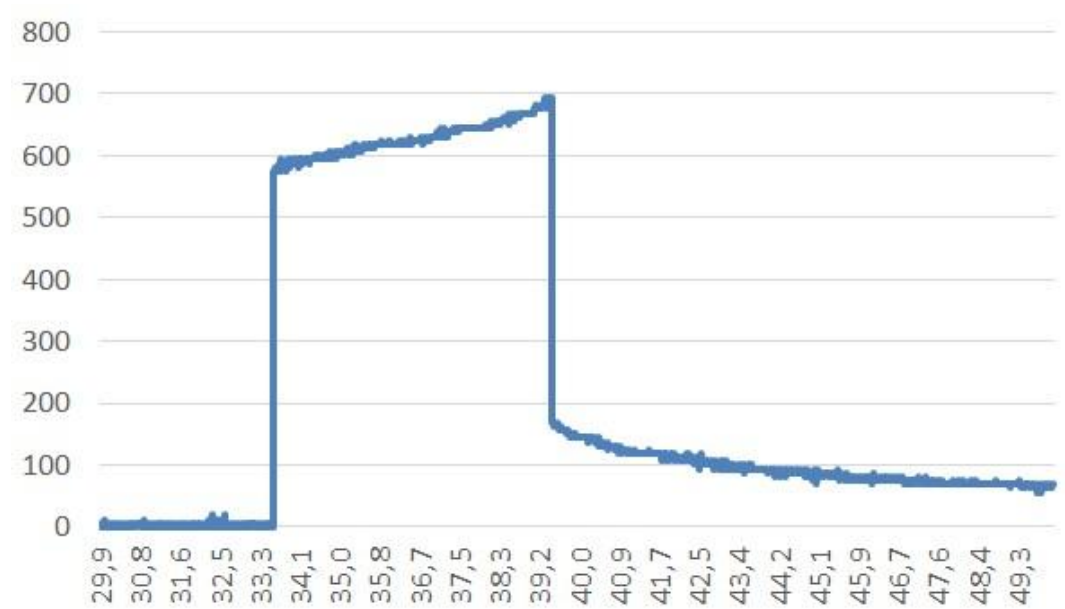

Fig. 8. The transient process in the primary $\mathrm{HV}$ winding (BC pins), the secondary LV winding (BC pins) are closed. At a time of $33.5 \mathrm{~s}$, a DC voltage of $8 \mathrm{~V}$ was applied to the HV through a resistance of $47 \mathrm{Ohms}$; at a time of $39.5 \mathrm{~s}$, the $\mathrm{HV}$ winding was closed. The $\mathrm{X}$ axis is time, $\mathrm{s}$; the $\mathrm{Y}$ axis is voltage amplitude, $\mathrm{mV}$, at a resistance of $10 \mathrm{Ohms}$ (current measurement in the HV primary winding)

Further DC voltage of $8 \mathrm{~V}$ (through an active resistance of $10 \mathrm{Ohms}$ ) was applied to the secondary LV transformer winding ( $b c$ pins), the current through the winding was measured by the voltage drop at a resistance of $1 \mathrm{Ohm}$. A clear difference between the transient process in the absence (Fig. 9) and in the presence (Fig. 10) of inter turn fault (additionally wound one shortcircuited turn on the B phase core) was observed. 


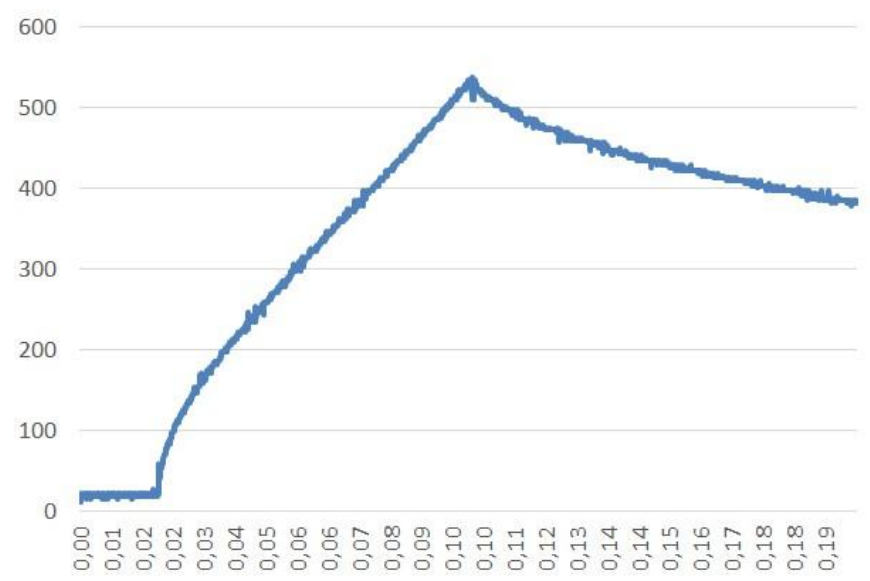

Fig. 9. The transient process in the secondary LV winding ( $b c$ pins). At time of $0.02 \mathrm{~s}$ a constant voltage of $8 \mathrm{~V}$ through a resistance of $10 \mathrm{Ohms}$ was applied to the $\mathrm{LV}$; at time of $0.10 \mathrm{~s}$, the $\mathrm{LV}$ winding was closed. The $\mathrm{X}$ axis is time, $\mathrm{s}$; the $\mathrm{Y}$ axis is voltage amplitude, $\mathrm{mV}$, at a resistance of 1 Ohms (current measurement in the LV secondary winding)

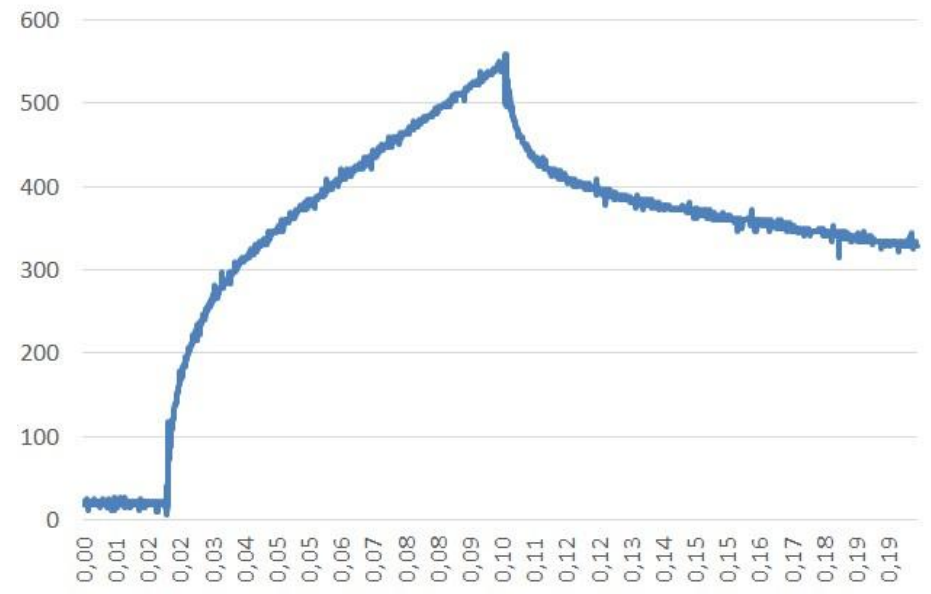

Fig. 10. The transient process in the secondary LV winding ( $b c$ pins) in the presence of inter turn fault (additionally wound one short-circuited turn on the B phase core).

At time of $0.02 \mathrm{~s}$ a constant voltage of $8 \mathrm{~V}$ through a resistance of $10 \mathrm{Ohms}$ was applied to the LV; at time of $0.10 \mathrm{~s}$, the $\mathrm{LV}$ winding was closed. The $\mathrm{X}$ axis is time, $\mathrm{s}$; the $\mathrm{Y}$ axis is voltage amplitude, $\mathrm{mV}$, at a resistance of $1 \mathrm{Ohms}$ (current measurement in the LV secondary winding)

\section{Conclusions}

Thus, in the proposed method for detection the inter turn faults of transformed windings, the transients are measured in wide ranges of times, which allows tuning away from transformer magnetization currents, by measuring the transient in the fault itself, namely in the short-circuited turns of the transformer winding. This solves the task of detecting the inter turn faults in the transformer windings in a wide range of damaged (closed) turns.

The author expresses his gratitude to Badretdinov Nail (head of the laboratory of the educational and research center "Electric Power Engineering" of KSPEU) and Zapechelnyuk Eduard (head of the laboratory of the department "Relay protection and automation" of KSPEU) for assistance in measurements. 


\section{References}

1. Bartley W. Analysis of Transformer Failures. International Association of Engineering Insurers 36 th Annual Conference. Stockholm, Sweden, 2003.

2. Pyatkov AV. Determination of inter turn fault in the windings of a power transformer with switching without excitation. In the collection: Energetics - to the agro-industrial complex of Russia. South-Ural State Agrarian University. 2017. pp. 156-160.

3. Oliveira L. Comparing Power Transformer Turnto-Turn Faults Protection Methods: Negative Sequence Component Versus Space Vector Algorithms. Oliveira L, Cardoso AJM. IEEE Transactions on Industry Applications. 2017. Vol.53: 2817-2825.

4. Tytko O. Definition of turn-fault of stator winding induction motor on the basis of the compensation magnetic field. O Tytko, AV Khudiakov. Технічна електродинаміка. 2017. № 1. С. 58-61.

5. Fedotov GI. Turn fault of a power transformer and methods for diagnosing them. Fedotov G.I., Golgovskikh AV. Society, science, innovations (NPK-2016) Collection of articles 2nd ed, revised and updated. Vyatka State University. 2016. pp. 2080-2083.

6. Sheryazov SK. Monitoring Device for Power Transformers 6-10. 0.4 kV. Sheryazov S.K., Pyatkov A.V. Proceedings of the LV Intern. Scientific. -Tech. conf. "Achievements of science - agro-industrial production." Chelyabinsk: SUSU. 2016. P. 240-244.

7. Ivanova ZG. Development of a device for detecting inter turn fault in the windings of dry power transformers. Ivanova ZG, Makarova NL. Vestnik Moskovskogo gosudarstvennogo agroinzhenernogo universiteta im. V.P. Goryachkina. VP. 2013. № 1 (57). P. 30-31.

8. Makarova NL. Diagnosing the state of isolation of power transformers of rural electric networks. Makarova NL, Akhmetshin RS. monograph. M .: FGBOU VPO MSAU, 2012.pp 90 .

9. Stanley HH. Power System Relaying. Third Edition. Stanley H. Horowitz, Arun G. Phadke. doi:10.1002/9780470758786. 2008 Research Studies 10. Mustafin RG. Utility model "Device for detecting windings short circuits of transformer windings Patent. RF 07.11.2017 Bull. N 20 Accessed: 02.02.2017.

\section{Литература}

1. Bartley W. Analysis of Transformer Failures // International Association of Engineering Insurers 36th Annual Conference. Stockholm, Sweden, 2003.

2. Пятков А.В. Устройство определения витковых замыканий в обмотках силового трансформатора с переключением без возбуждения // Энергетика агропромышленному комплексу РОССИИ. Южно-Уральский государственный аграрный университет, 2017. С. 156-160.

3. Oliveira L. Comparing Power Transformer Turnto-Turn Faults Protection Methods: Negative Sequence Component Versus Space Vector Algorithms / L. Oliveira, A.J.M. Cardoso // IEEE Transactions on Industry Applications. 2017. Vol. 53. P. 2817-2825.

4. Tytko O. Definition of turn-fault of stator winding induction motor on the basis of the compensation magnetic field / Tytko O., Khudiakov A.V. // Технічна електродинаміка. 2017. № 1. С. 58-61.

5. Федотов Г.И. Витковые замыкания силового трансформатора и методы их диагностирования / Г.И. Федотов, А.В. Голговских // Общество, наука, инновации (НПК-2016):. 2-е издание, исправленное и дополненное. Вятский государственный университет. 2016. С. 20802083.

6. Шерьязов С.К. Устройство мониторинга силовых трансформаторов 6-10/0,4 кВ / С.К. Шерьязов, А.В. Пятков // Материалы LV Междунар.науч.-техн. конф. «Достижения науки - агропромышленному производству». Челябинск : ЮУрГАУ, 2016. С. 240-244.

7. Иванова 3.Г. Разработка устройства для выявления витковых замыканий в обмотках сухих силовых трансформаторов / З.Г. Иванова, Н.Л.Макарова. //Вестник Московского государственного агроинженерного университета им. В.П. Горячкина. 2013. № 1 (57). С. 30-31.

8. Макарова Н.Л. Диагностирование состояния изоляции силовых трансформаторов сельских электрических сетей: монография / Н.Л. Макарова, Р.С. Ахметшин. М.: МГАУ, 2012. 90 с. 9. Stanley H. H. Power System Relaying, Third Edition / Stanley H. Horowitz, Arun G. Phadke // Print ISBN:9780470057124, |Online ISBN:9780470758786. 2008 Research Studies Press Limited.

10. Мустафин Рамиль Гамилович «Устройство обнаружения витковых замыканий обмоток 
Проблемы энергетики, 2019, том 21, № 3

трансформаторов» Патент РФ 11.07.2017. Бюл. № 20 Ссылка активна на: 02.02.2017.

\section{Authors of the publication}

Ramil G. Mustafin - candidate of physical and mathematical sciences, the associate professor at "Relay protection and automation of electrical power systems", Kazan State Power Engineering University.

Received

December 29, 2018 